\title{
Reopening of the Occluded Saphenous Vein Composite Grafts After Coronary Artery Bypass Grafting
}

\author{
Min-Seok Kim ${ }^{1}$ and Ki-Bong $\mathrm{Kim}^{2}$ \\ ${ }^{1}$ Hanseo Hospital \\ ${ }^{2}$ Myongji Hospital
}

September 24, 2021

\begin{abstract}
Background. We have observed reopening of the occluded "no-touch" saphenous vein (NT SV) composite grafts on follow-up angiograms in patients who underwent coronary artery bypass graftings (CABG). Methods. Between 2008 and 2018,1283 patients received NT SV conduits without or with surrounding pedicle tissue as composite grafts based on the in situ left internal thoracic artery (ITA) for CABG and underwent early postoperative angiographies. Among the 1283 patients, 53 patients showed 55 occluded SV conduit anastomoses, and 46 patients who had 48 occluded SV anastomoses were re-evaluated by 1-year postoperative angiographies. Results. Early postoperative angiographies in 1283 patients demonstrated overall occlusion rates of $1.2 \%$ (56/4518); occlusion rates of the ITA and SV were $0.08 \%(1 / 1259)$ and $1.7 \%$ (55/3260), respectively. One-year angiograms demonstrated that 14 occluded SV anastomoses (29.2\% [14/48 occluded SV]) of 14 patients became patent. Reopening of occluded SV conduits occurred more frequently in NT SV with pedicle tissue than in NT SV without pedicle tissue $(45.0 \%[9 / 20]$ versus $17.9 \%$ [5/28]; $\mathrm{P}=0.057)$. When we examined the preoperative and 1-year postoperative angiograms, reopening of the occluded $\mathrm{SV}$ conduits was not related with progression $(\mathrm{P}=0.258)$ or preoperative reversibility score $(\mathrm{P}=0.115)$ of native target coronary artery disease. Conclusions. More than a quarter of the occluded SV composite grafts on early postoperative angiograms were patent in the 1-year angiograms. The reopening rates were higher in patients who had received NT SV conduits with pedicle tissue than those who had received NT SV conduits without pedicle tissue.
\end{abstract}

\section{Introduction}

The saphenous vein (SV) is still the most commonly used secondary conduit for myocardial revascularization even though it has disadvantages of declining patency with time and resultant worse clinical outcomes compared with patency and outcomes of the internal thoracic artery (ITA) conduit [1]. Of numerous efforts to overcome the structural and functional limitations of SV conduit, the "no-touch" SV (NT SV) harvesting technique with or without a surrounding pedicle tissue and the surgical strategy of using the NT SV as part of a composite graft based on the left ITA have demonstrated good SV conduit patency rates comparable to arterial conduit patency rates [2-4]. Another recent study from our group demonstrated that NT SV conduits harvested with pedicle tissue further improved the early and 1-year patency of SV composite grafts, compared with NT SV conduits harvested without pedicle tissue [5]. When investigating the serial angiograms of NT SV composite grafts, we observed reopening cases of previously occluded NT SV conduits that were not reported in the literature.

The aims of the present study were (1) to assess the occlusion rates of NT SV composite grafts as seen in early postoperative angiograms; (2) to re-evaluate the occluded NT SV composite grafts by 1-year postoperative angiography; and (3) to elucidate the mechanism of NT SV composite graft reopening found during 1-year follow-up.

\section{Materials and Methods}


The institutional review board reviewed the study protocol and approved the present study as a minimal risk retrospective study (approval number H-2009-014-1154) that did not require individual patient consent. Of the 1746 patients who had undergone isolated CABG between January 2008 and December 2018 at Seoul National University Hospital, off-pump CABG (OPCAB) had been performed in 1711 patients (98.0\%). Of the 1711 patients, 1293 patients had received NT SV conduits as a Y- $(\mathrm{n}=1105)$ or an I-composite $(\mathrm{n}=272)$ graft based on the in situ left ITA for myocardial revascularization. Ninety-four patients had received NT SV conduits as both Y- and I- composite grafts. Early (1.4 \pm 1.3 days) postoperative angiograms that were performed in $99.2 \%$ of patients $(1283 / 1293)$ demonstrated 55 occluded SV conduit anastomoses in 53 patients. Of the 53 patients, 46 patients who had 48 occluded SV anastomoses were re-evaluated by 1-year (13.0 \pm 1.7 months) postoperative angiographies and were analyzed in the present study. One-year angiograms demonstrated reopened SV conduits in 14 patients (Group R) and persistently occluded SV conduits in 32 patients (Group O)(Figure 1).

\section{Operative Techniques and Revascularization Strategies}

The basic surgical procedures and strategies of OPCAB and harvesting technique of the SV have been previously described [5]. Saphenous vein harvest was performed using an open technique. The SV from a lower leg was chosen as opposed to the upper leg SV to decrease the possibility of size mismatch with native coronary arteries or ITA. Prior to October 2013, the NT SV was harvested without surrounding pedicle tissue, in which the manipulation and tension of the SV were minimized during harvest and manual intraluminal dilatation was avoided. The vein was gently separated from the bed using scissors, leaving small amount of perivascular adipose tissue in place. After October 2013, the NT SV was harvested with surrounding pedicle tissue, whereby the SV pedicle was harvested along with an approximately 3- to 5-mm wide margin of adjacent adipose tissues on both sides of the SV and thin layers of adherent connective tissues posteriorly, in addition to minimized manipulation and avoidance of manual intraluminal dilatation of the SV. Immediately after the harvest, the reversed SV was anastomosed to the side of the left ITA to construct a Y-composite graft or to the distal end of the left ITA to construct an I-composite graft. After the Y-composite graft was constructed, the left anterior descending coronary artery (LAD) territory commonly was revascularized first by using the left ITA while the distal end of the SV conduit was dilated spontaneously by the native flow and pressure of the left ITA. By using the SV as a composite graft, the left circumflex coronary artery (LCX) territory was then revascularized, followed by the right coronary artery (RCA) territory. A sequential anastomotic technique was used for complete revascularization when more than two coronary arterial anastomoses were needed. All the diseased left coronary territories that had had [?]70\% diameter stenosis and the right coronary territories that had had [?]90\% stenosis were considered for revascularization using SV composite grafts based on the left ITA.

We examined the anastomosis status with transit-time flow measurement (TTFM; Medi-Stim AS, Oslo, Norway) after performing each anastomosis and just before pericardial closure, and revised it if there was any abnormal finding in TTFM [6]. All patients received aspirin therapy (100mg daily) until the day of surgery and resumed it as soon as possible after surgery, usually 1 day postoperatively. Clopidogrel (75mg daily) was added simultaneously to aspirin for 1 year postoperatively. If the patient had a high blood level of low-density lipoprotein cholesterol $(>70 \mathrm{mg} / \mathrm{dL})$, a statin therapy was initiated and maintained postoperatively.

\section{Evaluation of Preoperative Angiography}

Coronary angiography was performed using a standard femoral or radial artery approach with a $5 \mathrm{Fr}$ or $6 \mathrm{Fr}$ diagnostic catheter. After administration of $200 \mu \mathrm{g}$ of intracoronary nitroglycerin, angiography was performed to allow for the best possible visualization of the stenosis. A visual estimation of the maximal degree of anatomic stenosis was performed by 2 independent cardiologists. The degree of coronary artery stenosis was categorized as intermediate (diameter stenosis [?]70\% but <90\%) or severe ([?]90\% stenosis).

\section{Postoperative Angiographic Follow Up}

Early postoperative and 1-year follow-up angiographies were performed as a postoperative evaluation strategy for CABG patients at our institution, regardless of the presence or absence of anginal symptoms. Those 
patients who had died, had refused angiographic evaluation, or had renal function impairment were excluded from the angiographic follow-up. However, patients receiving renal replacement therapy were included in the angiographic follow-up. Occluded composite graft was defined as distal graft and distal native grafted coronary artery flow not opacified as shown by graft angiography, and also retrograde graft flow not visualized by native coronary angiography. All the early occluded conduits were evaluated by coronary angiography. Of the 53 patients who showed occluded SV conduits, 45 patients were re-evaluated by 1-year postoperative coronary angiography. One patient who had been reluctant to undergo coronary angiographic follow-up evaluation had undergone multidetector computed tomography (MDCT) angiography as an alternative evaluation method and showed occluded SV anastomoses as well. The coronary angiograms and MDCT angiograms were reviewed by consensus of 2 specialists in each study.

Myocardial Single-Photon-Emission Computed Tomography (SPECT)

Thallium-201 rest/adenosine stress technetium-99m-methoxyisobutylisonitrile-gated SPECT was performed preoperatively. The reconstructed images were analyzed using an automatic quantifying software package (AutoQUANT, Philips Medical Systems, Milpitas, CA) after overall image quality was assessed by 2 experts. A 20-segment model was adopted for regional analysis. Resting and stress segmental myocardial perfusion was quantified by measuring radioactivity and expressed as the percentage of the maximal radioactivity uptake. The reversibility score, defined as a measure of rest minus stress perfusion values, was used as an indicator of the reversibility of perfusion impairment. Of the 4 RCA territory segments, 2 segments (segment numbers 6 and 12) were subtended to the posterior descending coronary artery (PDA) territory and were analyzed to elucidate the mechanism of SV reopening grafted to the PDA (Figure 2).

\section{Statistical Analysis}

Statistical analysis was performed with R software, version 3.6.0 (R Foundation for Statistical Computing, Vienna, Austria). Continuous data were expressed as the mean \pm standard deviation for normally distributed variables or as medians (interquartile ranges) for non-normally distributed variables according to the Shapiro-Wilk test, and categoric data were expressed as count (percentage). Comparisons between continuous variables were made using Student's $t$-test for normally distributed data or the Wilcoxon rank-sum test for non-normally distributed data based on the Shapiro-Wilk test. Categoric variables were compared using a chi-squared test. When [?]20\% of expected counts were [?]5, however, Fisher's exact test was used.

\section{Results}

\section{Patient Characteristics and Operative Data}

The study patients who had occluded SV conduits and were reevaluated by 1-year angiographies included 37 men and 9 women with a mean age of $65.9+-10.7$ years. When we compared group $\mathrm{R}$ with group $\mathrm{O}$, there were no differences in demographic data and preoperative risk factors between the 2 groups (Table 1). The median number of distal anastomoses per patient was $4.0[3,4]$ and the median number of distal anastomoses per SV conduit was $3.0[2.0,3.8]$. The percentage of SV harvested with pedicle tissue was higher in group R than in group $\mathrm{O}$, with marginal significance $(64.3 \%$ [9/14] versus $31.2 \%[10 / 32] ; P=0.077)$. However, there were no differences in other operative data, including the median number of distal anastomoses per patient, median number of anastomoses per SV conduit, and percentages of SV anastomosed to each coronary artery territory, between the 2 groups (Table 2).

\section{Early Postoperative Angiographic Results}

The overall early occlusion rate in 1283 patients was $1.2 \%$ (56/4518); occlusion rates of ITA and NT SV were $0.08 \%(1 / 1259)$ and $1.7 \%$ (55/3260), respectively. Of the 55 occluded SV anastomoses in 53 patients, $41 \mathrm{SVs}$ were grafted to the RCA territory (32 posterior descending arteries, 8 right posterolateral arteries, and $1 \mathrm{RCA}$ ), $13 \mathrm{SVs}$ were grafted to the obtuse marginal arteries, and $1 \mathrm{SV}$ was grafted to the diagonal artery. The SV occlusions occurred at the terminal $(n=50,90.9 \%)$ or sequential $(n=5,9.1 \%)$ anastomosis of SV composite grafts. The occlusion rates were lower in patients using the NT SV with pedicle tissue than 
in patients using the NT SV without pedicle tissue, with marginal significance (1.3\% [23/1797] versus $2.2 \%$ [32/1463]; $P=0.062)$.

One-Year Postoperative Angiographic Results and Reopening of Occluded SV Composite Grafts

Of the 55 occluded SV anastomoses on early postoperative angiograms, $48 \mathrm{SV}$ anastomoses in 46 patients were re-evaluated by 1-year postoperative angiography and $14 \mathrm{SV}$ conduits $(29.2 \%)$ of 14 patients had become patent (Figure 3). The coronary artery territories where reopening of the SV conduits occurred were 11 RCA (8 posterior descending arteries, 3 right posterolateral arteries) and 3 LCX (obtuse marginal arteries) territories. Reopening of the SV conduits occurred at the terminal $(n=11)$ or sequential $(n=3)$ anastomosis of SV composite grafts. Reopening of occluded SV conduits occurred more frequently in NT SV with pedicle tissue than in NT SV without pedicle tissue, with marginal significance (45.0\% [9/20] versus $17.9 \%$ $[5 / 28] ; P=0.057)$. When we examined the preoperative and 1-year postoperative angiograms, progression of native target coronary artery disease was found in 4 reopened SV territories and 6 persistently occluded SV territories, respectively (35.7\% [5/14] versus $17.6 \%$ [6/34]; $P=0.258)$. Of the 13 patients who had reopened conduits in the 1-year angiograms, 6 patients were followed up more than 5 years and underwent the 5 -year angiographic studies, which revealed patency maintained in all 6 reopened SV conduits.

\section{Preoperative SPECT Results in Patients Who Had an Occluded Conduit to PDA}

Both the rest and stress SPECT tests were performed preoperatively in 22 of 30 patients who showed an occluded SV conduit to the posterior descending coronary artery (PDA) on early postoperative angiograms (group $\mathrm{R}, \mathrm{n}=5$; group $\mathrm{O}, \mathrm{n}=17$ ). The reversibility score of PDA territory was lower in group $\mathrm{R}$ than in group $\mathrm{O}$, but with no statistical significance $(9.4+-13.1$ versus $22.8+-16.5 ; P=0.115)$.

\section{Comment}

The present study demonstrated 3 main findings. First, the early postoperative occlusion rate of the SV was $1.7 \%$ in patients who had received the NT SV conduit as a composite graft based on the in situ left ITA. The occlusion rate tended to be lower in patients who had received the NT SV conduit with pedicle tissue than in patients who had received the NT SV conduit without pedicle tissue. Second, more than $25 \%$ of the occluded $\mathrm{SV}$ conduit anastomoses seen in early postoperative angiograms were patent in the 1-year angiograms. The reopening rates tended to be higher in patients who had received the NT SV conduit with pedicle tissue than in patients who had received the NT SV conduit without pedicle tissue. Third, the reopening of the SV conduits took place irrespective of the reversibility of perfusion impairment in the preoperative SPECT results or the progression of native target coronary artery disease in the 1-year angiograms.

Arterial conduits have the advantage of superior long-term patency in CABG compared with vein grafts [7, 8]; however, development of perioperative spasm in the arterial conduits has been indicated as a drawback that might cause graft failure [9]. Of the arterial conduits used in CABG, observation of a patent free radial artery conduit that was occluded immediately after the operation provided the momentum for revival of use of the radial artery in CABG [10]. In another study which included 976 patients who received right gastroepiploic artery (RGEA) conduits in CABG, 9 of 23 patients who had RGEA conduit occlusions at early angiography showed patent RGEA conduits ( 7 composite and 2 in situ grafts) at 1 year [11].

The pathogenesis of SV conduit occlusion forms a continuum between early thrombosis within the first postoperative month, followed by intimal hyperplasia between 1 month and 1 year, and subsequent atherosclerotic change [12]. Platelet inhibitor therapy has been suggested to be of significant benefit on an early postoperative phase of platelet thrombotic occlusion and a late phase of occlusion toward the end of the first postoperative year, in which the intimal hyperplasia is superimposed by platelet thrombi [13]. One previous study documented spontaneous late canalization of aortocoronary SV conduits that were found to be occluded on 4-year postoperative angiogram but were patent on 10-year angiogram [14]. Although the mechanism of recanalization of aortocoronary SV conduits was unknown, the possibility of medical treatment was raised [14].

To the best of our knowledge, however, the reopening of occluded SV composite grafts has not been doc- 
umented previously. In the present study, the SV was harvested using the NT technique with or without pedicle tissue to preserve the endothelial integrity and function of the SV [15-17]. The reversed SV was then anastomosed to the in situ left ITA to construct a composite graft, continuously exposing the SV to endothelium-protective substances, such as NO released from the left ITA [5,15]. In addition, it has been suggested that the NT SV composite grafts based on the ITA go through a process of advantageous negative remodeling because the SV showed decreased lumen diameter but a similar ratio of intima-media thickness to that of the left ITA during the first postoperative year [18]. In the present study, the occlusion rates were lower and reopening rates of occluded SV conduits were higher in patients who received the NT SV with pedicle tissue than in patients who received the NT SV without pedicle tissue, although the statistical significance was marginal. The current study failed to demonstrate any correlation between the preoperative reversibility score or progression of native target coronary artery disease and the conduit reopening at the territory of SV occlusion. A further effort to preserve the endothelial integrity of the NT SV and using the NT SV as a composite graft based on the ITA might have resulted in the lower early occlusion and higher reopening rates of the SV conduits. We suggest that the early occlusion of the SV conduits can be presumed to be the result of thrombotic occlusion at the anastomosis site and resolved by the revascularization strategy using the NT SV composite graft based on the in situ ITA, in combination with postoperative dual antiplatelet therapy.

This study has limitations that must be recognized. First, this was a retrospective observational study from a single institution and the number of the study patients was relatively small. Second, 7 patients (13.2\%) who had shown occluded SV anastomoses but were not re-evaluated by 1-year postoperative angiography were excluded in the present study. Third, although the NT SV composite graft with pedicle tissue was suggested to be related with the reopening of the SV in the 1-year postoperative angiograms, the statistical significance was marginal for drawing a definite conclusion, probably due to the small sample size and the low incidence of the event.

\section{References}

1. Hillis LD, Smith PK, Anderson JL, Bittl JA, Bridges CR, Byrne JG, et al. 2011 ACCF/AHA guideline for coronary artery bypass graft surgery. J Am Coll Cardiol. 2011;58:e123-210.

2. Samano N, Geijer H, Liden M, Fremes S, Bodin L, Souza D. The no-touch saphenous vein for coronary artery bypass grafting maintains a patency, after 16 years, comparable to the left internal thoracic artery: A randomized trial. J Thorac Cardiovasc Surg. 2015;150:880-8.

3. Kim M-S, Hwang HY, Kim JS, Oh SJ, Jang M-j, Kim K-B. Saphenous vein versus right internal thoracic artery as a Y-composite graft: Five-year angiographic and clinical results of a randomized trial.J Thorac Cardiovasc Surg. 2018;156:1424-33.

4. Hwang HY, Lee Y, Sohn SH, Choi JW, Kim K-B. Equivalent 10-Year angiographic and long-term clinical outcomes with saphenous vein composite grafts and arterial composite grafts. $J$ Thorac Cardiovasc Surg.Available at:https://doi.org/10.1016/j.jtcvs.2020.01.109. Accessed May 14, 2020.

5. Kim YH, Oh HC, Choi JW, Hwang HY, Kim K-B. No-touch saphenous vein harvesting may improve further the patency of saphenous vein composite grafts: early outcomes and 1-year angiographic results.Ann Thorac Surg. 2017;103:1489-97.

6. Kim K-B, Kang CH, Lim C. Prediction of graft flow impairment by intraoperative transit time flow measurement in off-pump coronary artery bypass using arterial grafts. Ann Thorac Surg.2005;80:594-8.

7. Harskamp RE, Lopes RD, Baisden CE, de Winter RJ, Alexander JH. Saphenous vein graft failure after coronary artery bypass surgery: pathophysiology, management, and future directions. Ann Surg . 2013;257:824-33.

8. de Vries MR, Simons KH, Jukema JW, Braun J, Quax PHA. Vein graft failure: from pathophysiology to clinical outcomes. Nat Rev Cardiol. 2016;13,451-70.

9. He GW, Taggart DP. Spasm in arterial grafts in coronary artery bypass grafting surgery. Ann Thorac Surg . 2016;101:1222-9.

10. Acar C, Jebara VA, Portoghese M, et al. Revival of the radial artery for coronary artery bypass grafting. Ann Thorc Surg . 1992;54:652-9. 
11. Huh J-H, Lee K-H, Cho KR, Hwang HY, Kim K-B. Spasm and reopening of the right gastroepiploic artery conduit after coronary artery bypass grafting. Ann Thorac Surg . 2017;104:138-44.

12. Motwani JG, Topol EJ. Aortocoronary saphenous vein graft disease: pathogenesis, predisposition, and prevention. Circulation . 1998;97:916-31.

13. Fuster V, ChesebroJJ. Aortocoronary artery vein-graft disease: experimental and clinical approach for the understanding of the role of platelets and platelet inhibitors. Circulation . 1985;72(6 Pt 2):V65-70.

14. McCance AJ. Spontaneous late recanalization of occluded saphenous vein coronary artery grafts. Cardiology . 1991;78:168-70.

15. Tsui JC, Souza DS, Filbey D, Bomfim V, Dashwood MR. Preserved endothelial integrity and nitric oxide synthase in saphenous vein grafts harvested by a 'no-touch' technique. Br J Surg. 2001;88:120915.

16. Hwang HY, Kim M-A, Seo JW, Kim K-B. Endothelial preservation of the minimally manipulated saphenous vein composite graft: Histologic and immunohistochemical study. J Thorac Cardiovasc Surg . 2012;144:690-6.

17. Dashwood MR, Tsui JC. 'No-touch' saphenous vein harvesting improves graft performance in patients undergoing coronary artery bypass surgery: A journey from bedside to bench.Vascul Pharmacol . 2013;58:240-50.

18. Hwang HY, Koo B-K, Oh SJ, Kim K-B. Morphologic changes of the saphenous vein Y-composite graft based on the left internal thoracic artery: 1-year intravascular ultrasound study. J Thorac Cardiovasc Surg . 2015;149:487-93.

Table 1. Preoperative Characteristics and Risk Factors of the Study Patients

\begin{tabular}{|c|c|c|c|c|}
\hline & $\begin{array}{l}\text { All study patients ( } \\
\mathrm{n}=46)\end{array}$ & Group R (n=14) & Group O $(\mathrm{n}=32)$ & $P$ value \\
\hline Age, y & $65.9 \pm 10.7$ & $66.0 \pm 13.8$ & $65.9 \pm 9.3$ & 0.971 \\
\hline Female & $9(19.6)$ & $4(28.6)$ & $5(15.6)$ & 0.539 \\
\hline $\begin{array}{l}\text { Body mass index, } \\
\mathrm{kg} / \mathrm{m}^{2}\end{array}$ & $25.0 \pm 2.8$ & $25.0 \pm 3.3$ & $25.1 \pm 2.6$ & 0.982 \\
\hline Current smoker & $16(34.8)$ & $4(28.6)$ & $12(37.5)$ & 0.740 \\
\hline Hypertension & $34(73.9)$ & $8(57.1)$ & $26(81.2)$ & 0.178 \\
\hline Diabetes mellitus & $16(34.8)$ & $6(42.9)$ & $10(31.2)$ & 0.671 \\
\hline Dyslipidemia & $15(32.6)$ & $6(42.9)$ & $9(28.1)$ & 0.523 \\
\hline Atrial fibrillation & $2(4.3)$ & $1(7.1)$ & $1(3.1)$ & $>0.999$ \\
\hline $\begin{array}{l}\text { Chronic renal } \\
\text { failure }\end{array}$ & $6(13.0)$ & $2(14.3)$ & $4(12.5)$ & $>0.999$ \\
\hline $\begin{array}{l}\text { Chronic } \\
\text { obstructive } \\
\text { pulmonary } \\
\text { disease }\end{array}$ & $0(0.0)$ & $0(0.0)$ & $0(0.0)$ & NA \\
\hline $\begin{array}{l}\text { Peripheral } \\
\text { vascular } \\
\text { obstructive } \\
\text { disease }\end{array}$ & $9(19.6)$ & $3(21.4)$ & $6(18.8)$ & $>0.999$ \\
\hline History of stroke & $8(17.4)$ & $3(21.4)$ & $5(15.6)$ & 0.956 \\
\hline $\begin{array}{l}\text { Previous } \\
\text { percutaneous } \\
\text { coronary } \\
\text { intervention }\end{array}$ & $9(19.6)$ & $1(7.1)$ & $8(25.0)$ & 0.317 \\
\hline $\begin{array}{l}\text { Acute myocardial } \\
\text { infarction ([?]30 } \\
\text { d) }\end{array}$ & $9(19.6)$ & $2(14.3)$ & $7(21.9)$ & 0.847 \\
\hline
\end{tabular}




\begin{tabular}{|c|c|c|c|c|}
\hline & $\begin{array}{l}\text { All study patients ( } \\
\mathrm{n}=46)\end{array}$ & Group R (n=14) & Group O $(\mathrm{n}=32)$ & $P$ value \\
\hline Unstable angina & $26(56.5)$ & $10(71.4)$ & $16(50.0)$ & 0.212 \\
\hline $\begin{array}{l}3 \text {-vessel disease } \\
\text { with or without } \\
\text { left main disease }\end{array}$ & $40(87.0)$ & $13(92.9)$ & $27(84.4)$ & 0.651 \\
\hline Left main disease & $13(28.3)$ & $5(35.7)$ & $8(25.0)$ & 0.699 \\
\hline $\begin{array}{l}\text { Left ventricular } \\
\text { ejection fraction } \\
<.35\end{array}$ & $6(13.0 \%)$ & $1(7.1)$ & $5(15.6)$ & 0.756 \\
\hline $\begin{array}{l}\text { Stenosis degree of } \\
\text { coronary artery } \\
\text { grafted by } \\
\text { occluded conduit }\end{array}$ & & & & $>0.999$ \\
\hline intermediate & $6(13.0)$ & $2(14.3)$ & $4(12.5)$ & \\
\hline severe & $40(87.0)$ & $12(85.7)$ & $28(87.5)$ & \\
\hline
\end{tabular}

Values are mean $\pm \mathrm{SD}$ or $\mathrm{n}(\%)$.

Table 2. Operative Data

\begin{tabular}{|c|c|c|c|c|}
\hline & $\begin{array}{l}\text { All Study Patients } \\
(\mathrm{n}=46)\end{array}$ & Group R $(\mathrm{n}=14)$ & Group $\mathrm{O}(\mathrm{n}=32)$ & $P$ value \\
\hline Elective operation & $43(93.5)$ & $13(92.9)$ & $30(93.8)$ & $>0.999$ \\
\hline $\begin{array}{l}\text { Number of } \\
\text { anastomoses per } \\
\text { patient }\end{array}$ & $4[3,4]$ & $4[4,4]$ & $4[3,4]$ & 0.137 \\
\hline $\begin{array}{l}\text { Number of } \\
\text { anastomoses per } \\
\text { saphenous vein } \\
\text { conduit }\end{array}$ & $3[2.0,3.8]$ & $3[3,4]$ & $3[2,3]$ & 0.307 \\
\hline $\begin{array}{l}\text { Saphenous vein as } \\
\text { a Y-composite } \\
\text { graft }\end{array}$ & $41(89.1)$ & $11(78.6)$ & $30(93.8)$ & 0.314 \\
\hline $\begin{array}{l}\text { Saphenous vein } \\
\text { with pedicle } \\
\text { tissue }\end{array}$ & $19(41.3)$ & $9(64.3)$ & $10(31.2)$ & 0.077 \\
\hline $\begin{array}{l}\text { Saphenous vein } \\
\text { sequential } \\
\text { anastomoses }\end{array}$ & $44(95.7)$ & $14(100.0)$ & $30(93.8)$ & 0.864 \\
\hline $\begin{array}{l}\text { Saphenous vein } \\
\text { anastomosed to } \\
\text { LAD territory }\end{array}$ & $32(69.6)$ & $11(78.6)$ & $21(65.6)$ & 0.596 \\
\hline $\begin{array}{l}\text { Saphenous vein } \\
\text { anastomosed to } \\
\text { LCX territory }\end{array}$ & $43(93.5)$ & $14(100.0)$ & $29(90.6)$ & 0.592 \\
\hline $\begin{array}{l}\text { Saphenous vein } \\
\text { anastomosed to } \\
\text { RCA territory }\end{array}$ & $37(80.4)$ & $13(92.9)$ & $24(75.0)$ & 0.317 \\
\hline
\end{tabular}


Values are median [interquartile ranges] or $\mathrm{n}(\%)$. LAD = left anterior descending coronary artery; LCX = left circumflex coronary artery; RCA = right coronary artery.

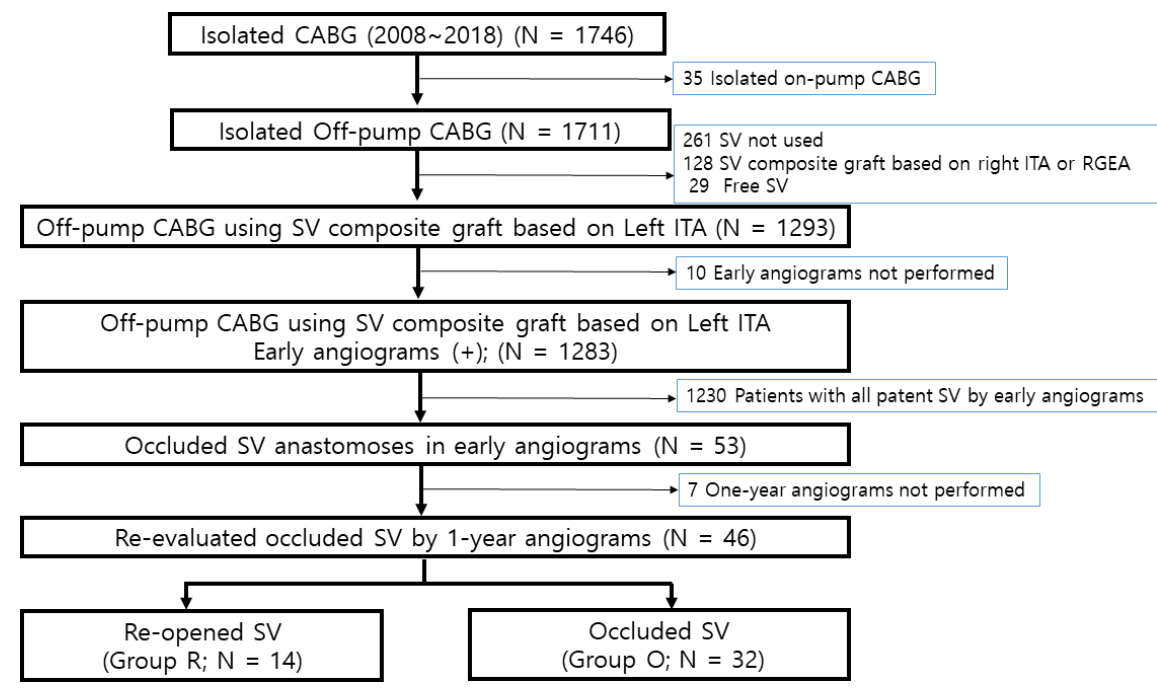

Figure 1. Summary flow diagram showing inclusion of the patient groups. CABG, coronary artery bypass grafting; ITA, internal thoracic artery; RGEA, right gastroepiploic artery; SV, saphenous vein.
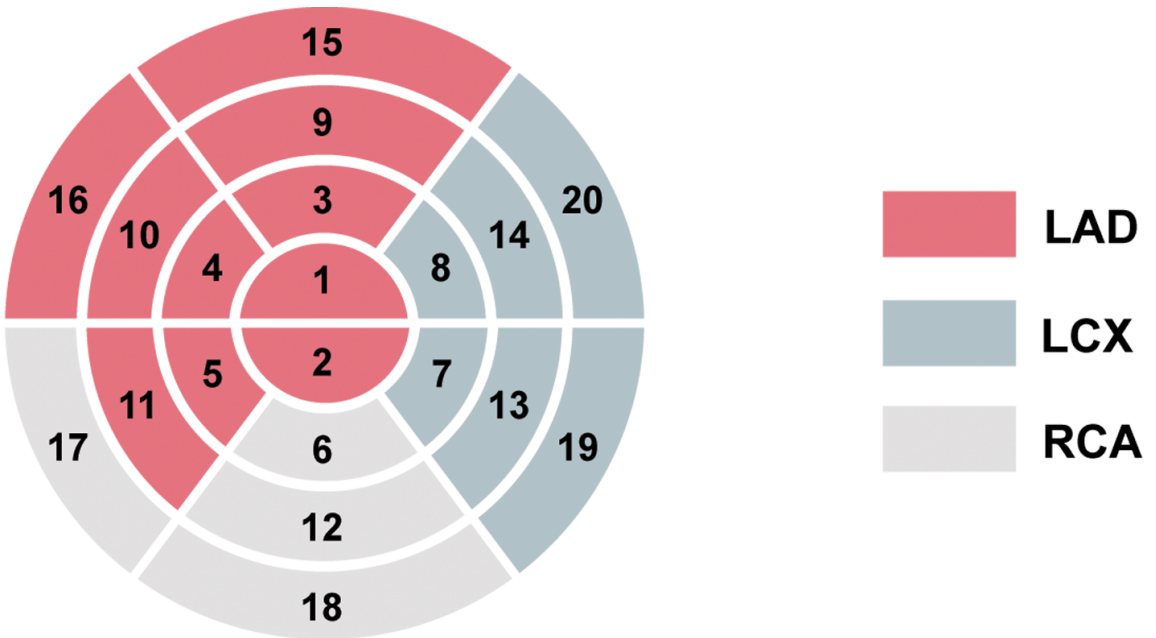

Figure 2. Diagram showing a 20-segment model of stress/rest single photon emission computed tomography. Ten, 6 and 4 segments subtended to the left anterior descending coronary artery (LAD), left circumflex coronary artery $(L C X)$ and right coronary artery (RCA) territories, respectively. 


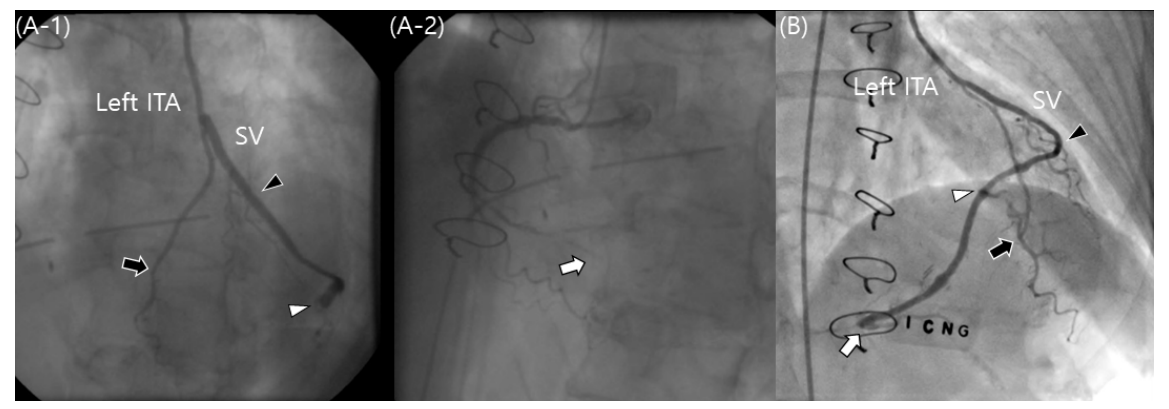

Figure 3. (A-1) Reopening of saphenous vein (SV) composite graft based on the in situ left internal thoracic artery (ITA) in a 64-year-old man. The left ITA was anastomosed to the left anterior descending coronary artery (black arrows), and the $S V$ conduit was anastomosed to the diagonal (black arrowheads), obtuse marginal (white arrowheads), and posterior descending (PDA [white arrows]) arteries. The SV conduit distal to its anastomosis with the obtuse marginal artery was not opacified as shown by graft angiography on early postoperative angiogram. (A-2) The $S V$ conduit anastomosed to the PDA also was not visualized retrogradely as shown by native right coronary angiography. (B) The SV conduit anastomosed to the PDA was reopened as shown by graft angiography on 1-year angiogram. 